\title{
Celdood, een nieuw perspectief op leven
}

Citation for published version (APA):

Reutelingsperger, C. P. M. (2010). Celdood, een nieuw perspectief op leven. Maastricht University. https://doi.org/10.26481/spe.20101015cr

Document status and date:

Published: $15 / 10 / 2010$

DOI:

$10.26481 /$ spe.20101015cr

Document Version:

Publisher's PDF, also known as Version of record

\section{Please check the document version of this publication:}

- A submitted manuscript is the version of the article upon submission and before peer-review. There can be important differences between the submitted version and the official published version of record.

People interested in the research are advised to contact the author for the final version of the publication, or visit the DOI to the publisher's website.

- The final author version and the galley proof are versions of the publication after peer review.

- The final published version features the final layout of the paper including the volume, issue and page numbers.

Link to publication

\footnotetext{
General rights rights.

- You may freely distribute the URL identifying the publication in the public portal. please follow below link for the End User Agreement:

www.umlib.nl/taverne-license

Take down policy

If you believe that this document breaches copyright please contact us at:

repository@maastrichtuniversity.nl

providing details and we will investigate your claim.
}

Copyright and moral rights for the publications made accessible in the public portal are retained by the authors and/or other copyright owners and it is a condition of accessing publications that users recognise and abide by the legal requirements associated with these

- Users may download and print one copy of any publication from the public portal for the purpose of private study or research.

- You may not further distribute the material or use it for any profit-making activity or commercial gain

If the publication is distributed under the terms of Article $25 \mathrm{fa}$ of the Dutch Copyright Act, indicated by the "Taverne" license above, 


\section{Maastricht University}

Chris P. M. Reutelingsperger

Faculty of Health, Medicine and Life Sciences

\section{Celdood, een nieuw perspectief op leven}


Celdood, een nieuw perspectief op leven 


\section{Colofon}

Ontwerp en print: Océ Business Services, Maastricht

In samenwerking met $A Z M, M U M C+$

Omslag: Een fragment van 'De opstanding van Jezus' van Rembrandt ( \pm 1635$)$.

ISBN: 978-905-681-3468

NUR: 881

Alle rechten voorbehouden. Niets uit deze uitgave mag worden verveelvoudigd, opgeslagen in een geautomatiseerd gegevensbestand of openbaar gemaakt worden, zonder voorafgaande schriftelijke toestemming van de auteur of uitgever. 


\section{Celdood, een nieuw perspectief op leven}

\section{Rede}

uitgesproken bij de aanvaarding van het ambt van hoogleraar in de Biochemie van Apoptose aan de Faculty of Health, Medicine and Life Sciences van de Universiteit Maastricht

Maastricht, 15 oktober 2010

Chris P. M. Reutelingsperger 
Celdood, een nieuw perspectief op leven 
Mijnheer de Pro-Rector

Decaan van de Faculteit Health, Medicine and Life Sciences

Gewaardeerde collega's

Lieve familie en vrienden

Geachte toehoorders.

5 weken geleden bracht ik een bezoek aan Noord Korea. In de loop der tijd had ik een beeld van Noord Korea gevormd op basis van nieuwsberichten van onze media. Dit beeld werd op 28 september in het NOS Journaal van $20.00 u$ nog eens volledig uit de doeken gedaan. Het was een mistroostig beeld dat de geur van dood zwaar uitademde. Na een bezoek van 5 dagen was ik in complete verwarring. Het beeld dat ik ter plekke had gevormd was precies het tegenovergestelde. Een vriend van mij hield mij voor dat ik waarschijnlijk in Pyongyang in een cocon had vertoefd. Misschien heeft hij gelijk, misschien ook niet. Wel sterkte deze ervaring mij in de overtuiging dat beelden gevormd dienen te worden aan de hand van gedegen feitenonderzoek en dat eenmaal gevormde beelden een eigen leven kunnen gaan leiden ook als ze door de tijd zijn vervreemd van de werkelijkheid.

Nu zie ik u denken 'welke richting gaat dit op?'. Voordat u een verkeerd beeld vormt wil ik u zeggen dat dit de richting op gaat van een ander onderwerp waarvan het beeld in de afgelopen decennia drastisch is veranderd door wetenschappelijk denken en gedegen onderzoek. Dit onderwerp is de dood. Het beeld van de dood werd in de afgelopen eeuwen voornamelijk bepaald door het onomkeerbare waarmee hij een einde maakt aan het leven. En door religieus denken waarmee de dood toegang verschaft tot een hiernamaals. Aardig is om in dit verband te vermelden dat Albert Einstein ooit opperde dat religieus denken een uitgang tracht te vinden waar geen deur is. ' Samengevat, het beeld van de dood was niet positief om allerlei redenen die nauwelijks van wetenschappelijke aard waren. Af en toe werd vanuit een positief perspectief naar de dood gekeken. Zo merkte de satiricus en schrijver Jonathan Swift op, bij de meesten van u bekend als de schrijver van Gullivers Travels, dat het onmogelijk is dat iets zo natuurlijk en noodzakelijk als de dood ooit door de voorzienigheid geschapen was als een kwaad voor de mens. ${ }^{2}$ Met het verwoorden van deze gedachte kon Swift destijds niet bevroeden hoe waar zijn woorden eens zouden blijken te zijn. Maar, dan wel op een vlak waar men in zijn tijd nog nauwelijks weet van had. 
Het wetenschappelijk deel van mijn openbare les begint bij de formulering van de celtheorie. De celtheorie beschrijft dat het lichaam is opgebouwd uit cellen en dat de cel de kleinst levende eenheid is. De theorie beschrijft bovendien dat cellen gevormd worden uit reeds bestaande cellen door celdeling. De basis voor deze theorie werd gelegd door tijdgenoten van Jonathan Swift in de 17e en begin 18e eeuw. De formulering van de uiteindelijke theorie geschiedde in de 19 e eeuw en komt op naam van de fysioloog Theodor Schwann, de botanicus Matthias Schleiden en de arts Rudolph Virchow. Wetenschappers van de 19 e en zoe eeuw tot ongeveer midden jaren 70 vestigden hun aandacht voornamelijk op de celdeling en hadden nauwelijks oog voor doodgaande cellen. Men zou dit kunnen wijten aan het negatieve beeld van de dood dat bewust of onbewust toch het denken van de wetenschappers beïnvloedde. Desondanks waren er in de 19e eeuw wetenschappers die op een of andere manier celdood in hun publicaties opnamen. Zo beschreef de zoöloog Carl Vogt in 1842 het doodgaan van cellen tijdens de metamorfose van de vroedmeesterpad. ${ }^{3}$ De bioloog Walther Flemming tekende in 1885 celfiguren die ontstaan tijdens de regressie van het Graafse follikel in het konijn. ${ }^{4}$ Als je met de huidige kennis naar deze celfiguren kijkt herken je meteen de apoptotische cellen die er tussen zitten. Apoptose is een actieve vorm van celdood die ik verderop in deze les uitgebreider zal behandelen. Deze vroege observaties hebben destijds niet geleid tot een diepere wetenschappelijke uitwerking van de betekenis van celdood voor het leven. Het zal u waarschijnlijk niet zijn ontgaan dat het met name onze oosterburen zijn geweest die met hun nauwkeurige waarnemingen het overgrote deel van de beschrijving en de uitwerking van de celtheorie voor hun rekening hebben genomen. Het Lutherse denken kan een rol hebben gespeeld bij het weglaten van celdood in de theorievorming.

Maar dat verklaarde niet alles. Van invloed was ook de algemeen aanvaarde overtuiging dat het verdwijnen van cellen het gevolg was van necrose dat als passief en aspecifiek werd beschouwd. Deze constellatie van gedachten weerhield onderzoekers ervan wetenschappelijk onderzoek naar celdood op te zetten en uit te voeren.

1972 wordt beschouwd als het jaar van de omwenteling voor celdood onderzoek. In dat jaar publiceerden drie angelsaksische pathologen, Kerr, Currie en Wyllie een artikel waarin ze het verdwijnen van cellen uit weefsel beschreven als een specifiek proces dat een homeostatische functie 
vervult en dat de omvang van cel populaties regelt in fysiologische en pathologische situaties. ${ }^{5} \mathrm{Zij}$ waren ervan overtuigd dat het proces van celdood dat zij hadden waargenomen fundamenteel verschilt van necrose en gaven het de naam apoptose. Apoptose betekent in het Grieks "het vallen van de bladeren". Men zou verwachten dat celdood door deze publicatie vanuit een nieuw perspectief zou worden benaderd en dat het onderzoek naar celdood eindelijk leven werd ingeblazen. Maar niets is zo lastig als het veranderen van verankerde beelden. Ook wetenschappers hebben met dit fenomeen te maken. In een editorial van de Lancet van 11 november 1972 betoogde de editor dat Kerr, Wyllie en Currie er weliswaar goed aan hadden gedaan de aandacht te vestigen op celdood in de beschrijving van fysiologie en pathologie van weefsels maar dat hij zich wel afvroeg of het wijs was geweest er de naam apoptose aan te verbinden. ${ }^{6}$

De wetenschappelijke belangstelling barstte echt los in de jaren 90 toen duidelijk werd dat de cel actief zelfmoord kan plegen met behulp van specifieke biochemie. Onder andere door onderzoek aan het spoelwormpje, de Caenorhabditis Elegans, kon men aantonen dat in de cel enzymen aanwezig zijn die op non-actief worden gehouden in de levende cel. Deze enzymen kunnen geactiveerd worden door de cel zelf maar ook door de omgeving van de cel die activatie van deze enzymen kan afdwingen. Eenmaal actief zullen de enzymen de constructie van de cel proteolytisch afbreken wat de dood van de cel betekent. De afbraak gaat gepaard met specifieke vormveranderingen die reeds in de $19 \mathrm{e}$ eeuw waren geobserveerd. Nu meer dan 100 jaar later zien we celdood als een actief en gereguleerd proces dat onmisbaar is voor het leven van het multicellulaire organisme.

Om $u$ een indruk te geven van de omvang van celdood in ons dagelijks leven geef ik $u$ een paar getallen. Ons volwassen lichaam produceert ongeveer een miljoen cellen per seconde door celdeling. Dit zijn bijna 90 miljard cellen per dag en meer dan 30 biljard cellen per jaar. Dat betekent dat het lichaam zijn gewicht per jaar zou verdubbelen alleen al door de aanmaak van nieuwe cellen. Toch gebeurt dit in de praktijk niet omdat celdood als compenserend mechanisme actief is. Per seconde sterven ongeveer een miljoen cellen door actieve celdood waarvan apoptose de meest voorkomende vorm is. Celdood zorgt dus voor de noodzakelijke balans waarmee het multicellulaire organisme homeostase kan verkrijgen en handhaven (Figuur 1). Celdood voorkomt dat ons lichaams- 


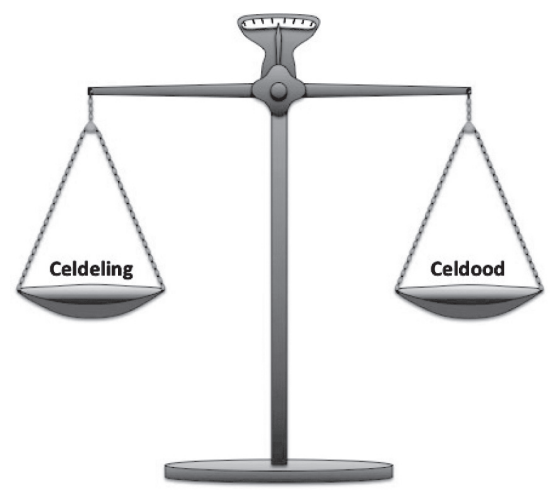

\section{Homeostasis}

Figuur 1: De balans tussen celdeling en celdood

gewicht toeneemt ten gevolge van een toename aan cellen door de voortdurende celdeling.

Welke cellen besluiten dood te gaan? Dat zijn verouderde cellen en cellen die hun functie vervuld hebben, uitgeput zijn en geen rol meer kunnen spelen. Maar ook cellen die schade in hun DNA hebben opgelopen, bijvoorbeeld door zonlicht of door een fout tijdens de celdeling. Cellen met DNA schade kunnen gevaarlijk worden voor het lichaam omdat ze kankercellen kunnen vormen. Zo ver komt het gelukkig in de meeste gevallen niet. DNA schade activeert een in de cel aanwezig veiligheidsmechanisme dat in eerste instantie probeert het beschadigd DNA te repareren. Lukt dat niet dan gaat het mechanisme verder en zorgt ervoor dat de biochemische zelfmoordmachine aan het werk wordt gezet. De cel pleegt zelfmoord en offert zich op in het belang van het multicellulaire organisme. Een ander voorbeeld van opoffering zien we als een cel door een virus geinfecteerd raakt. De cel kan dan besluiten zelfmoord te plegen zodat het virus niet wordt vermenigvuldigd. Met deze zelfmoordactie beschermt de cel zijn buurcellen voor virus infectie.

Celdood kan dus vergeleken worden met de meest onbaatzuchtige vorm van altruïsme in een sociale context. Momenteel heerst in de evolutiebiologie een discussie over de oorsprong van altruïstisch gedrag binnen een soort. De meeste theorieën richten zich op het gedrag van het individu als belangrijke selectie parameter voor behoud en verbetering van de 
soort. Een vergelijkbare rol speelt de dood op cellulair niveau voor het leven van het multicellulaire organisme.

Van al die doodgaande cellen in onze weefsels merken wij heel weinig dankzij een zeer efficiente opruimdienst. In het weefsel zijn fagocyten aanwezig die de zelfmoordenaars snel herkennen en vervolgens opruimen. De fagocyt is een cel die in staat is een andere cel op te eten en af te breken tot de bouwstenen. De fagocyt hergebruikt de bouwstenen van de dode cel zelf of geeft ze af aan de omringende cellen. Op deze wijze wordt de dode cel volledig gerecycled. Als we op zoek zouden gaan naar sporen van zelfmoord in gezond weefsel dan komen we met lege handen terug want de opruimdienst van fagocyten werkt snel en grondig.

Alle cellen in ons lichaam bezitten eiwitten die nodig zijn om zelfmoord te plegen. Maar er zijn cellen waarvan we willen dat ze het celdood programma nooit zullen activeren. Dat zijn bijvoorbeeld hersencellen en hartspiercellen. Als deze cellen doodgaan worden ze met moeite vervangen door nieuwe cellen. Deze cellen bevatten dan ook extra veiligheidsmechanismen die zelfmoord impulsen stevig de kop indrukken.

De balans tussen celdeling en celdood kan verstoord raken en een verstoorde balans kan leiden tot ziekten. Zo kan het dat er te weinig celdood is ten opzichte van celdeling door bijvoorbeeld mutaties in genen die coderen voor eiwitten die betrokken zijn bij de executie van celdood. Dit doet zich voor bij ziekten als kanker en autoimmuunziekten. Bijvoorbeeld kankercellen kunnen defecte eiwitten hebben die onvoldoende in staat zijn het zelfmoordprogramma te activeren terwijl ze wel kunnen delen. Het resultaat is een toename aan kankercellen. Therapieën die gericht zijn op stimulatie van het zelfmoordprogramma kunnen de balans weer herstellen.

De balans kan ook de andere kant uitslaan door een teveel aan celdood. Dit speelt bijvoorbeeld bij de ontwikkeling van metabool syndroom, tijdens neurodegeneraties zoals Alzheimer Dementia en in de aanloop naar hartfalen.

Maar ook een acuut hart- en herseninfarct veroorzaken celdood. Het infarct genereert zulke krachtige impulsen dat zelfs hartspiercellen en hersencellen zelfmoord plegen ondanks de aanwezigheid van sterke veiligheidsmechanismen. Herstel van de balans kan in deze situaties bereikt worden door therapieën die gericht zijn op het remmen van celdood. 
Ik hoop dat dit beknopt overzicht $u$ duidelijk heeft gemaakt dat het beeld van de dood in de loop der tijd sterk is veranderd door wetenschappelijk denken en dat onderzoek naar de biochemische processen van celdood nieuwe diagnostiek en medicijnen kan opleveren waarmee ziekten met een verstoorde balans behandeld kunnen worden.

In mijn laboratorium onderzoeken wij de doodgaande cel van de buitenkant. Tijdens de executie van het celdoodprogramma verandert de structuur van de buitenkant dusdanig dat een fagocyt kan zien dat de cel zelfmoord pleegt. Vanuit de visie wat de fagocyt ziet moeten wij ook kunnen zien organiseer ik mijn onderzoek in een richting die uiteindelijk moet leiden naar nieuwe mogelijkheden voor diagnostiek en doelgerichte afgifte van medicijnen.

Alvorens ik met $u$ die mogelijkheden bespreek geef ik $u$ eerst een korte les elementaire biochemie van de cel zodat $u$ de verdere uitleg van mijn onderzoek moeiteloos kunt volgen.

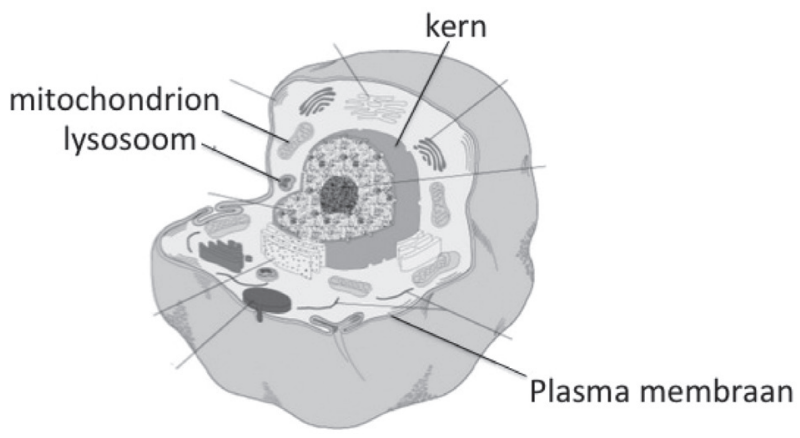

Figuur 2: Schematische weergave van de cel

Uit de cel, die hierboven mij is geprojecteerd, is een hap genomen zodat we een kijkje in de cel kunnen nemen (Figuur 2). Het interieur van de cel bestaat uit een soep van eiwitten, het cytoplasma genoemd. In deze soep bevinden zich een deel van de eiwitten waarmee de cel zelfmoord kan plegen. In het cytoplasma liggen ook de celorganellen zoals de kern, waar de genetische informatie ligt opgeslagen, de mitochondriën, die de energie leveren, en de lysosomen, die niet-functionele en overtollige bestanddelen afbreken tot bouwstenen die hergebruikt kunnen worden. Het cytoplasma en de organellen worden bij elkaar gehouden door de 
plasma membraan, die ervoor zorgt dat de cel een eenheid is en blijft. Ik laat $u$ nu schematisch zien hoe de plasmamembraan is opgebouwd (Figuur 3).

buitenkant van de cel

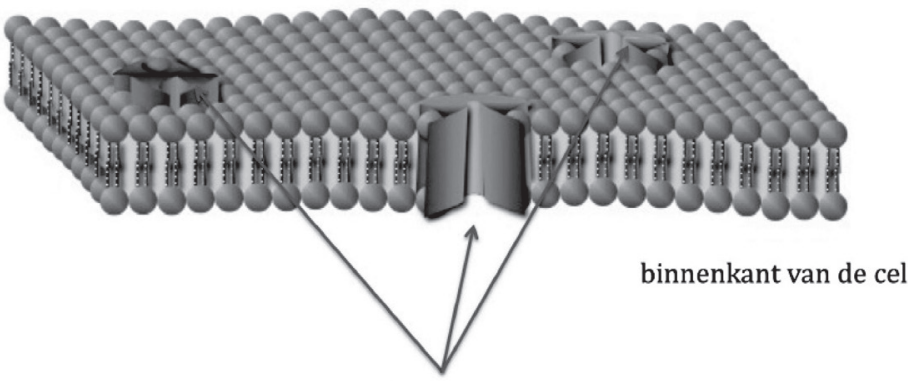

Eiwitten

fosfolipid

Figuur 3: Schematische weergave van de bilaag van de plasma membraan volgens het vloeibaar mosaic model van Singer en Nicolson ${ }^{7}$

De membraan is een dubbellaag van fosfolipiden waarin zich eiwitten bevinden. De fosfolipiden en eiwitten kunnen onafhankelijk van elkaar bewegen. Dit dynamisch model van een plasma membraan werd in 1972 gepostuleerd door Jonathan Singer samen met zijn student Garth Nicolson.7 Nu bijna 40 jaar later en ontelbare experimenten met membranen achter de rug staat het vloeibaar mosaic model nog altijd overeind. Voor deze les vraag ik uw aandacht voor het fosfolipid fosfatidylserine. Ongeveer 10-15\% van de fosfolipiden van een cel bestaat uit fosfatidylserine, dat in het nu geprojecteerde figuur rood is gekleurd (Figuur 4).

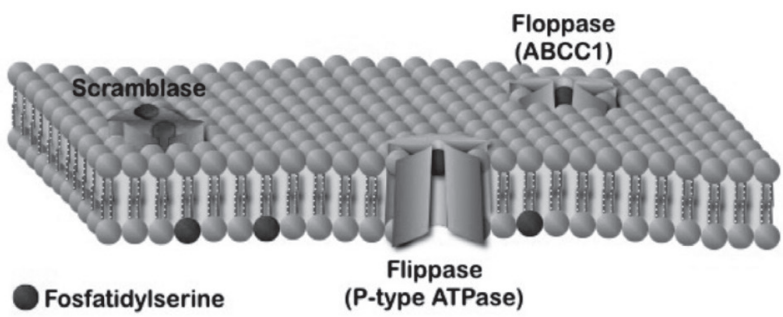

Figuur 4: Schematische weergave van de plasma membraan van de levende cel met fosfatidylserine en de eiwitten die foasfatidylserine transporteren 
Verder ziet u de eiwitten flippase, floppase en scramblase die transport van fosfatidylserine van de ene naar de andere laag mogelijk maken. Flippase stuurt fosfatidylserine van buiten naar binnen, floppase van binnen naar buiten en scramblase doet dit zowel van binnen naar buiten als van buiten naar binnen. De levende cel houdt flippase actief en scramblase inactief. Ik ben mij ervan bewust dat dit voor de niet inhoudsdeskundige te abstract overkomt vandaar dat ik de bewegingen aan de hand van een animatie probeer te verduidelijken. Hier ziet $u$ de bewegingen van fosfatidylserine in de plasma membraan van een levende cel. Wat valt u hierbij op? Natuurlijk verwacht ik van u geen antwoord. De levende cel zorgt dat fosfatidylserine met name aan de binnenkant van de cel blijft, en dat heeft een rede die ik verderop in deze les zal bespreken.

In 1992 publiceerde Valerie Fadok van het National Jewish Hospital in Denver een mijlpaal artikel in het onderzoek naar de structuurverandering van de plasma membraan tijdens celdood. ${ }^{8}$ Zij beschreef dat lymfocyten tijdens apoptose fosfatidylserine aan de buitenkant van de plasma membraan hebben.

Naar aanleiding van dit artikel weten we nu dat een celdood prikkel het celdood programma activeert met als gevolg een remming van flippase en een activatie van scramblase. In de volgende animatie is te zien welk effect dit heeft op de bewegingen van fosfatidylserine. Fosfatidylserine verschijnt in de buitenlaag van de plasma membraan (Figuur 5).

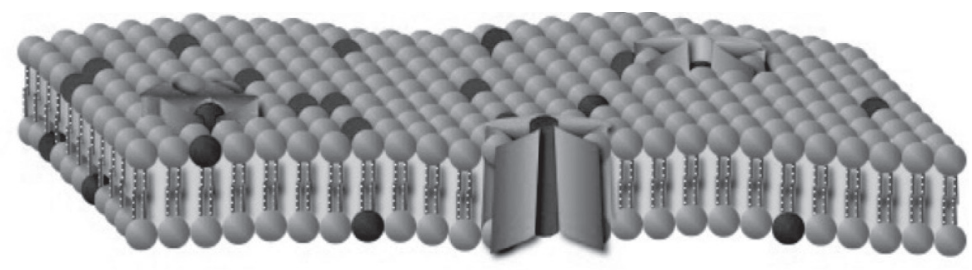

Figuur 5: Schematische weergave van de plasma membraan van de doodgaande cel met fosfatidylserine (rood) in de buitenste laag 
Deze verschijning blijft niet onopgemerkt. Fagocyten, die in het weefsel aanwezig zijn, hebben speciale ogen, de receptoren, waarmee ze het fosfatidylserine kunnen waarnemen. Bij het zien van dit fosfolipid gaan de alarmbellen rinkelen en worden mechanismen geactiveerd waarmee de fagocyt de cel onderwerpt aan een nauwkeurig onderzoek naar andere tekens van een op handen zijnde zelfmoord. Bij een positieve bevinding besluit de fagocyt de zelfmoordenaar op te ruimen, simpelweg door de cel op te eten en af te breken in de lysosomen tot bouwstenen. Zoals gezegd, het opruimen van celdood gebeurt snel en grondig in gezond weefsel. Daarentegen, ziek weefsel heeft een veel minder efficiente opruimdienst omdat het aanbod aan celdood te groot is of omdat de opruimdienst zelf hapert. Met als gevolg dat zieke weefsels veel dode cellen en resten van dode cellen bevatten.

Tot zover deze les over elementaire biochemie van de cel waarin ik $u$ heb uitgelegd dat de cel speciale aandacht besteedt aan het kenbaar maken van zijn besluit om zelfmoord te plegen. Niet omdat hij bij voorbaat spijtoptant is maar om ervoor te zorgen dat zijn dood geen nadelige gevolgen heeft voor zijn directe omgeving.

In mijn onderzoek maken wij gebruik van dit gegeven door fosfatidylserine te benutten als doelwit in het zichtbaar maken van celdood in ziek weefsel met behulp van Moleculair Imagen. Moleculair Imagen is een vrij jonge discipline die wetenschap en technologie combineert ten behoeve van de bestudering van cellulaire processen op moleculair niveau om zo kennis te vergaren over regulatie van deze processen in de complexiteit van het weefsel en om in staat te zijn ziektenprocessen reeds in een vroege fase vast te stellen op moleculair niveau.

Het Moleculair Imagen van fosfatidylserine, oftewel het zichtbaar maken van celdood, vergt de beschikking over een stof die met hoge affiniteit aan fosfatidylserine bindt, ook in de complexiteit van het weefsel. Dit brengt mij op een belangrijk punt van deze les, namelijk de ontdekking van het eiwit annexin A5. Dit eiwit heeft een hoge affiniteit voor fosfatidylserine en bindt met voorkeur aan plasma membranen die dit fosfolipid aan de buitenkant hebben.

Zoals zo vaak met ontdekkingen het geval wil zijn, was de ontdekking van annexin $\mathrm{A} 5$ niet het resultaat van een a priori aanwezig onderzoeksplan. Ik neem u nu mee terug naar het onderzoek van de capaciteitsgroep 
Biochemie in de begin jaren 8o. Onder leiding van Prof. Coen Hemker werden de biochemische processen van de bloedstolling onderzocht. Een aantal van de destijds nog onbeantwoorde vragen had betrekking op de initiatie van de bloedstolling door de wand van het bloedvat. Welke stollingsbevorderende structuren zijn in de vaatwand aanwezig, waar zitten ze en kunnen deze structuren trombose veroorzaken?

Prof. Gerard Hornstra had een project geschreven waarmee deze vragen beantwoord konden worden en was van mening dat ik een geschikte kandidaat was om het project succesvol uit te voeren. Als biochemicus opgeleid door Prof. Henk Van den Bosch aan de Universiteit van Utrecht deed ik wat bijna alle biochemici in die tijd met een dergelijke vraagstelling zouden doen, namelijk een bloedvat nemen, dit homogeniseren en dan het homogenaat testen in een reageerbuisproef. Per toeval stuitte ik op een eiwit in het homogenaat dat de bloedstolling niet activeerde maar remde. 9 Destijds was ik in het gezelschap van Biochemici die baanbrekend onderzoek deden naar de rol van fosfatidylserine in de bloedstolling. Prof. Rob Zwaal en Dr. Edouard Bevers onderzochten de rol van fosfatidylserine in bloedplaatjes en Prof. Jan Rosing en Dr. Guido Tans bestudeerden de katalyserende werking van fosfatidylserine in de bloedstolling. Achteraf kan ik constateren dat deze omgeving mede bepalend was voor de koerswijziging die ik aanbracht in mijn onderzoek. Het ontdekte antistollende eiwit, dat wij vasculair anticoagulans noemden, kortweg VAC, bleek namelijk aan fosfatidylserine te binden en daarmee de katalyserende werking van dit fosfolipid in de bloedstolling te neutraliseren. Zowel het eiwit als het antistollend mechanisme waren niet eerder beschreven in de literatuur. Gerard Hornstra adviseerde eerst een patent applicatie te schrijven en vervolgens pas een publicatie. Een gang van zaken welke in de Akademie van die dagen ongewoon was en door vele akademici beschouwd werd als 'not done'. De patent applicatie, welke het eiwit en het gebruik van het eiwit als geneesmiddel beschermde, bezorgde ons een omvangrijk onderzoekscontract met een farmaceutische industrie en voldoende financiële middelen waarmee ik het fundamenteel onderzoek kon voortzetten. De ontdekking bezorgde mij bovendien in 1987 een 5-jarige positie als onderzoeker van de Koninklijke Nederlandse Akademie der Wetenschappen.

Met behulp van 'State of the Art' technologie uit die tijd kraakten we de genetische code van VAC en kwamen tot de ontdekking dat het eiwit een lid is van de annexine familie van fosfolipid bindende eiwitten. 
Dientengevolge kreeg VAC vanaf dat moment de naam annexin A5. Er was intussen een grote vraag naar gezuiverd annexin A5 ontstaan. Om aan deze vraag te kunnen voldoen ontwikkelden wij een fermentatie-proces waarin bacteriën tot productiefabriekjes van het humane annexin $A_{5}$ waren omgevormd. Zo kregen wij de beschikking over een bijna onuitputtelijke bron van humaan annexin $\mathrm{A}_{5}$ waarmee we de binding aan fosfatidylserine diepgaand konden onderzoeken.

De eerder genoemde publicatie van Valerie Fadok bezorgde mijn onderzoek in 1992 alweer een onverwachte wending. Aangespoord door Fadok's publicatie en gestuurd door intuïtie schreef ik een patent applicatie waarin het gebruik van annexin $\mathrm{A}_{5}$ als detectiemiddel van celdood werd beschermd. In samenwerking met Prof. Istvan Vermes van het Medisch Spectrum Twente en wijlen professor emeritus Clemens Haanen publiceerden wij 2 jaar later een flow cytometrische methode waarin met behulp van fluorescent gelabeld annexin A5 de hoeveelheid apoptose in biologische samples gemeten kan worden. Deze publicatie is inmiddels de best geciteerde publicatie van deze Universiteit en fluorescent annexin $A_{5}$ is wereldwijd een van de meest gebruikte reagentia om apoptose in vitro te meten.

De cardioloog Prof. Leo Hofstra stapte eind jaren 90 mijn kamer binnen met de vragen of ik wist wat apoptose was en of ik geinteresseerd was in een samenwerking. Dit luidde het begin in van een vruchtbare samenwerking waarin we annexin $A_{5}$ omtoverden in een Moleculaire Imaging probe om apoptose in het hart van een patient met hartinfarct zichtbaar te maken. Met hulp van Prof. Guido Heidendal werden de benodigde vergunningen verkregen en werd annexin $\mathrm{A} 5$ gelabeld met het radioisotoop Technetium ${ }^{-99 m}$. Het plan was even eenvoudig als geniaal. Door het hartinfarct gaan hartspiercellen in apoptose. Als annexin A5-99mTechnetium in de bloedsomloop van de patient wordt gebracht dan zal het binden aan apoptotische hartspiercellen. Het radioactieve isotoop maakt het vervolgens mogelijk om met de beeldvormende techniek SPECT a poptose te meten. Dit heeft diagnostische waarde bij het bepalen van plaats en omvang van het infarct en bij het vaststellen van de werking van therapieën die gericht zijn op het remmen van celdood van hartspiercellen. Wat we wel nog nodig hadden was een gezonde vrijwilliger zodat we konden uitsluiten dat levende hartspiercellen in de complexiteit van het hartweefsel annexin A5 opnemen. De eerste en naar mijn beste weten laatste vrijwilliger was Leo Hofstra. Ik weet dat dit een verkeerd beeld kan 
geven maar ik kan u verzekeren dat zijn opoffering het verwachte resultaat opleverde en zeker niet heeft geleid tot zijn fagocytose. Integendeel zou ik zelfs durven beweren. Hier afgebeeld ziet u de resultaten van de beeldvorming van celdood in het hart van een patient die een acuut hartinfarct heeft gehad. De patient werd ingespoten met Thallium-201 en Technetium-annexin A5 (Figuur 6). Thallium is een radioisotoop dat onafhankelijk van Technetium in beeld kan worden gebracht. Links ziet $u$ het beeld met Thallium, in oranje/geel weergegeven, dat wordt opgenomen door levende hartspiercellen. Duidelijk is bij de pijl het defect in de hartspier te ontdekken ten gevolge van het infarct. Rechts ziet u de opname met Technetium-annexin A5, ook in oranje/geel weergegeven. Op de plek waar links het defect te zien is kunnen we rechts ophoping van annexin A5 zien. De lever licht op omdat lever en nieren annexin A5 uit de bloedbaan halen. Dit onderzoek leverde de eerste publicatie op waarin we aantoonden dat celdood in een patient op een positieve manier in beeld kan worden gebracht met Moleculair Imagen. ${ }^{10}$

Thallium-201

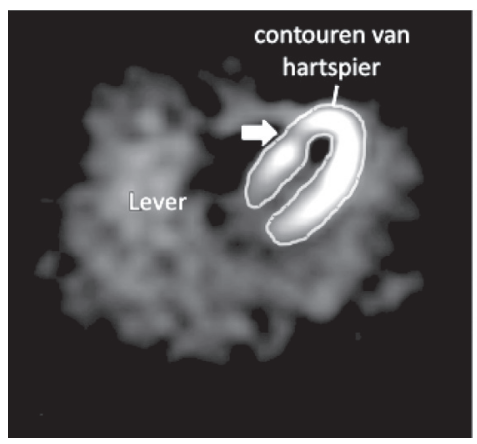

${ }^{99 m}$ Technetium-annexin 5

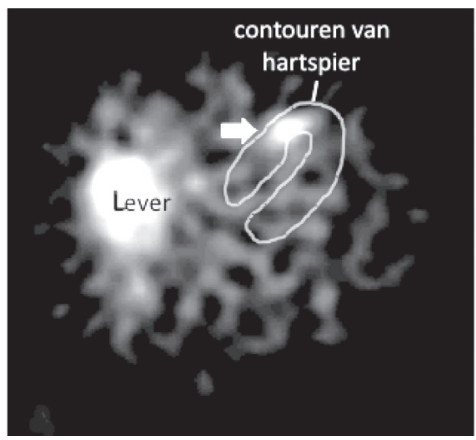

Figuur 6: Thallium en ${ }^{99 m}$ Technetium-annexin A5 SPECT van een patient met een acuut hartinfarct (aangepaste afbeelding uit de publicatie Hofstra L, e.a. Lancet (2000) 356:209).

Een acuut hartinfarct is vaak het gevolg van het scheuren van een atherosclerotische plaque in een van de kransslagaders. Onderzoek naar celdood en atherosclerose heeft laten zien dat celdood ook in de plaque aanwezig is en dat een toename van celdood een verhoogd risico op scheuren van de plaque betekent. In samenwerking met Prof. Jagat Narula van de University California Irvine hebben we kunnen aantonen dat de stabiliteit van de plaque bepaald kan worden aan de hand van het zichtbaar maken van celdood met annexin $\mathrm{A}_{5}$. Op basis van de resul- 
taten van experimenten met proefdieren besloten we patienten met atherosclerose te imagen met het Technetium-annexin A5 protocol. De eerste resultaten zijn veelbelovend maar geven ook aan dat er voldoende ruimte voor verbetering van het imaging protocol is.

Sinds kort weten we dat de dode cellen en celresten in de plaque mogelijk betrokken zijn bij de afzetting van kalkdeeltjes in de plaque. Kalkdeeltjes op hun beurt kunnen instabiliteit veroorzaken. Mijn onderzoeksgroep bestudeert nu onder leiding van Dr. Leon Schurgers de relatie tussen celdood en verkalking tijdens de atherogenese. Dit onderzoek zal naar verwachting nieuwe mogelijkheden opleveren voor diagnostiek en therapie van instabiele atherosclerotische plaque.

Celdood is ook van belang in de ziekte kanker. Zoals gezegd groeit een tumor vanwege een verstoorde balans tussen celdeling en celdood. Chemo- en radiotherapie kunnen de balans herstellen door celdood in de tumor te activeren. Helaas komt het voor dat een therapie niet aanslaat en nauwelijks celdood van betekenis veroorzaakt. In de meeste gevallen kan de behandelend arts het falen van een therapie pas vaststellen aan het einde van het protocol of als de therapie al een behoorlijke tijd wordt toegepast. De behoefte is groot om de effectiviteit in een vroeg stadium vast te stellen om niet-werkzame therapieën zo snel mogelijk te kunnen stoppen en, indien mogelijk, te vervangen door een andere therapie.

Het Technetium-annexin A5 imaging protocol wordt onderzocht op zijn diagnostieke waarde in het vroegtijdig vaststellen van de effectiviteit van een anti-kanker therapie. Het protocol is eenvoudig. Een week voor het starten van de therapie krijgt de patient Technetium-annexin $\mathrm{A}_{5}$ toegediend en wordt de opname in de tumor gemeten met SPECT. Binnen 5 dagen na de aanvang van de therapie wordt de patient opnieuw ge-imaged met het annexin A5 protocol. Indien de therapie aanslaat en tumorcellen doodt dan zal de opname van annexin A5 in de tumor zijn toegenomen ten opzichte van de eerste keer.

De SPECT opnamen die u boven mij ziet zijn gemaakt door de groep van Prof. Marcel Verheij van het NKI-Antoni van Leeuwenhoekziekenhuis in Amsterdam (Figuur 7). ${ }^{11}$ De patient heeft een folliculair lymfoom in het hals en nek gebied. De bovenste rij laat de SPECT opnames zien die gemaakt zijn voor de therapie en de onderste rij de opnames 4 dagen na radiotherapie. Duidelijk is te zien dat de tumor meer annexin A5 
opneemt ten gevolge van de behandeling. Dit is te zien aan de toegenomen intensiteit van de gele kleur. Met behulp van cytologie stelden de onderzoekers vast dat door de behandeling celdood in de tumor was toegenomen. 4 weken later kon met geaccepteerde criteria worden vastgesteld dat er bij de patient sprake was van complete remissie.

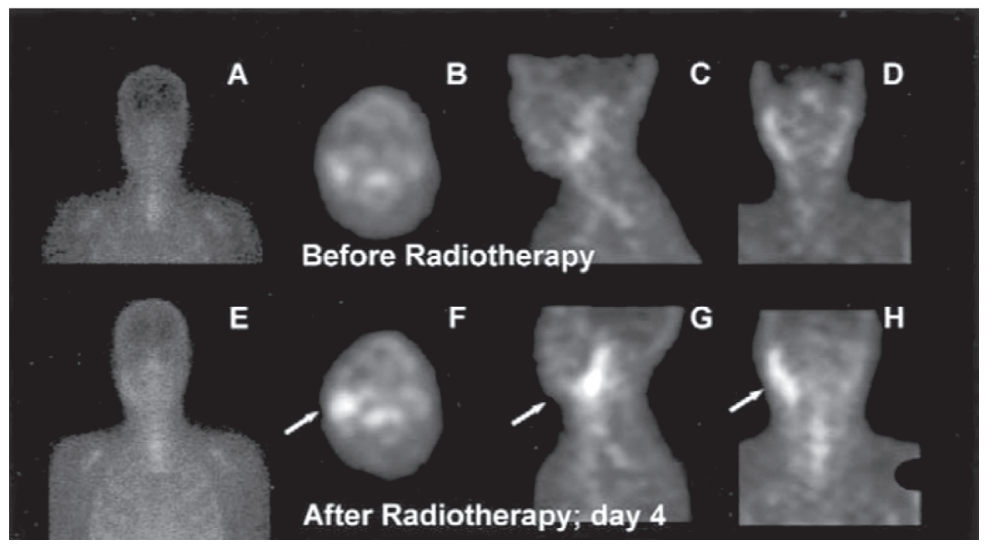

Figuur 7: Celdood imagen van een patient met folliculair lymfoom met behulp van ${ }^{99 m}$ Technetium-annexin A5 SPECT (overgenomen uit de publicatie Haas, R. e.a. Int. J. Radiation Oncology Biol. Phys. (2004) 59:782)

De twee voorbeelden die ik $u$ heb getoond illustreren het belang van celdood en de klinische betekenis die het zichtbaar maken van celdood kan hebben. Het annexins imaging protocol kan mogelijk een waardevolle bijdrage leveren aan diagnostiek en het vaststellen van de effectiviteit van therapie. We zijn echter nog ver verwijderd van een geregistreerde toepassing in de kliniek.

De preklinische en klinische ervaringen met het protocol maken duidelijk dat verbetering van resolutie en signaal-achtergrond verhouding zeer gewenst is om sensitivieteit en specificiteit te verbeteren.

Mijn onderzoeksgroep werkt aan de verbetering van deze imaging parameters door het eiwit annexin A5 met moleculair biologische technieken geschikt te maken voor bestaande en toekomstige technologieën. Zo kunnen we aan de hand van onze kennis over de structuur/functie relatie en met behulp van het door Dr. Gerry Nicolaes opgestarte mole- 
cular modeling binnen onze capaciteitsgroep het annexin A5 molecuul geschikt maken voor verschillende imaging modaliteiten en nieuwe imaging strategieën. Mijn laboratorium onderzoekt ook de mogelijkheden om met annexin $A_{5}$ varianten doelgericht medicijnen af te geven aan ziek weefsel met celdood. Inmiddels heeft mijn onderzoeksgroep een ze generatie annexin $\mathrm{A}_{5}$ met verbeterde eigenschappen gemaakt en is een ze generatie annexin A5 op komst. Met trots zeg ik $U$ dat mijn team in de afgelopen jaren een gesmeerd lopend platform heeft gebouwd waarmee binnen een aantal weken op gerichte wijze de genetische code van eiwitten veranderd kan worden en bacteriën omgevormd kunnen worden tot eiwitproducerende fabriekjes. Dit platform stelt ons in staat snel op nieuwe ontwikkelingen van andere disciplines in te springen. Zo ben ik sterk geinteresseerd in de ontwikkelingen op het gebied van de nanotechnologie waar nieuwe nanostructuren worden ontworpen om multimodaal te kunnen imagen en tegelijkertijd therapie te bedrijven. Nanostructuren staan mijns inziens aan de basis van een nieuw tijdperk van diagnostiek en therapie.

\section{Proefdierexperimenten en onderzoek}

Het onderzoek dat ik $u$ in deze les heb gepresenteerd, en medisch onderzoek in het algemeen, kan niet zonder het gebruik van proefdieren. Ziekteprocessen en effecten van nieuwe medicijnen dienen nu eenmaal op enig moment in de complexiteit van het proefdier bestudeerd te worden alvorens vertaling naar klinische toepassing mogelijk is. Zoals $\mathrm{u}$ ongetwijfeld weet is het gebruik van proefdieren een controversieel onderwerp dat tot heftige discussies kan leiden. Er zijn groeperingen in onze samenleving die fel gekant zijn tegen het gebruik van proefdieren en soms geen middel schuwen om hun standpunten te verduidelijken. Zij schetsen een ongenuanceerd en eenzijdig beeld van onnodig lijden van proefdieren. Ik kan u meedelen dat het werkelijke beeld er anders uitziet. Zoals gezegd, experimenten met proefdieren zijn noodzakelijk om de gewenste vooruitgang te boeken. Onderzoekers kunnen echter niet zo maar een experiment met proefdieren uitvoeren. Ze zullen eerst goed moeten nadenken over de verwachte resultaten en of deze verkregen kunnen worden met alternatieven. Indien dat niet kan, zal hij of zij zich moeten afvragen of de verwachte resultaten opwegen tegen het ongerief van het proefdier. De onderzoeker stelt vervolgens een onderzoeksplan op en laat dat toetsen door de dierexperimenten com- 
missie van de Universiteit. Na goedkeuring zullen de dierproeven met de grootst mogelijke zorgvuldigheid door bevoegde mensen worden uitgevoerd.

Helaas wordt de procedure wel eens als onnodig belastend en als een sta-in-de-weg van het onderzoek ervaren. Ik ben ervan overtuigd dat deze procedure met toetsing door de dierexperimenten commissie noodzakelijk is om verantwoord onderzoek met proefdieren te waarborgen. Een en ander van de procedure is vastgelegd in de Wet op de Dierproeven. En hierin schuilt tevens het gevaar. Onder maatschappelijke druk kan er een bureaucratisch gedrocht ontstaan door toespitsende wet- en regelgeving dat weliswaar proefdiergebruik toelaat maar praktisch bijna onmogelijk maakt. Dit moeten we met zijn allen zien te voorkomen. Beeldvorming over het nut en het gebruik van proefdieren speelt een belangrijke rol want deze zal bepalen of de maatschappelijke druk verder zal toenemen of juist zal afnemen. Hier ligt volgens mij een taak voor de Universiteiten. Zij dienen het juiste beeld breed onder de aandacht te brengen zodat er geen nieuwe obstakels komen voor het voor de samenleving zo belangrijke onderzoek met proefdieren.

\section{Universiteit en Industrie}

De explosieve toename aan kennis heeft er de afgelopen jaren voor gezorgd dat wetenschappelijk onderzoek een complexe bezigheid is geworden die je niet meer zo maar in je eentje uitvoert met de bedoeling een betekenisvolle vooruitgang te boeken. Tel daar bij op dat de technologieën waarmee onderzoeksvragen beantwoord kunnen worden steeds geavanceerder en duurder worden en steeds sneller vervangen worden door verbeterde technologieën, dan is het niet verbazingwekkend dat steeds grotere multidisciplinaire verbanden ontstaan welke samenwerken aan gemeenschappelijke doelen. Ook het onderzoek aan celdood vergt een multidisciplinaire aanpak met gebruik van geavanceerde technologieën. Vorig jaar heb ik het platform Euregional PACT II opgericht dat kennis, expertise en technologieën van verschillende Universiteiten uit de grensregio Vlaanderen-Nederland bundelt. Euregional PACT II beoogt met deze bundeling nieuwe op eiwitten gebaseerde theragnostica te ontwikkelen die diagnostisch en tegelijkertijd therapeutisch werkzaam zijn in ziekten waarin celdood een rol speelt. In dit project participeren de Universiteiten van Maastricht, Leuven, Antwerpen, Gent en Aken en 
de organisaties LifeTecZOne en FlandersBio. De organisaties LifeTecZOne en FlandersBio beschikken over een uitgebreid netwerk in de Life Science bedrijvensector en slaan een brug tussen universiteiten en bedrijven met als doel uitwisseling van kennis en kunde te stimuleren ten behoeve van innovatie van producten en productie-processen. Het uiteindelijke doel is nieuwe kennis en technologie via Life Science bedrijven zo snel mogelijk in de vorm van diagnostiek en behandelingen bij de patient te krijgen.

Euregional PACT II is mogelijk gemaakt door steun van de Europese unie met EFRO-gelden uit het Interreg IV programma van de grensregio Vlaanderen-Nederland. Ook de provincies Limburg, Noord-Brabant, Belgisch Limburg, Vlaams-Brabant, Antwerpen en Oost-Vlaanderen en de Nederlandse en Vlaamse overheid geven financiële steun aan Euregional PACT II. Deze brede steun illustreert hoe belangrijk de samenleving de samenwerking tussen Universiteiten en Industrie is gaan vinden.

Samenwerken met de Industrie was voor Universiteiten niet altijd vanzelfsprekend. Het is nog niet zo lang geleden dat de Universiteit een verbintenis met de Industrie vergeleek met het sluiten van een pact met de duivel. De Akademie boogt op een lange traditie waarin onafhankelijkheid centraal staat en samenwerken met Industrie geen plek had. Gelukkig heeft de Akademie tijdig ingezien dat traditie het fundament van de toekomst dient te zijn en niet de kerker van het verleden en heeft ze het heersende beeld dat samenwerken ten koste van de onafhankelijkheid zou gaan geleidelijk aan de kant kunnen zetten.

In de volgende dia schets ik u mijn beeld van een belangrijke uitbreiding van de Akademische traditie (Figuur 8).

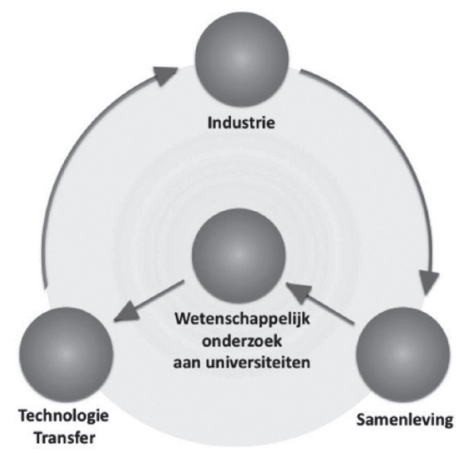

Figuur 8: De interactieve cyclus Universiteit - Industrie 
Ik zal u proberen uit te leggen waarom een dergelijke cyclus noodzakelijk is geworden aan de hand van een nieuw medicijn. Nieuwe medicijnen bereiken niet zo maar de patient. We stellen zeer hoge eisen aan de veiligheid en de werkzaamheid en dat brengt hoge ontwikkelingskosten met zich mee. Als resultaten van wetenschappelijk onderzoek de potentie hebben nieuwe medicijnen op te leveren dan heeft de Industrie alleen interesse te investeren in de ontwikkeling van die resultaten als deugdelijke technologie transfer mogelijk is wat in feite betekent dat de resultaten beschermd dienen te zijn of beschermd kunnen worden door patenten. Alleen op deze wijze kunnen resultaten van wetenschappelijk onderzoek in de vorm van nieuwe medicijnen bij de patient komen. De samenleving op haar beurt steunt wetenschappelijk onderzoek.

Uitdrukkelijk wil ik hier aan toevoegen dat dit niet betekent dat de samenleving alleen maar onderzoek dient te steunen dat via deze cyclus toepasbare resultaten oplevert. Onderzoek dat niet per se gericht is op toepassingen verdient zeker ook steun van onze samenleving. De verwondering en nieuwsgierigheid die ten grondslag liggen aan dit type onderzoek mogen wij nimmer opofferen aan de wetten van het kortstondig economisch nut.

Ik hoop dat ik $u$ heb kunnen overtuigen dat celdood in de loop der tijd een ander beeld heeft gekregen en dat het nu gezien wordt als een wezenlijk onderdeel van het leven. Wetenschappelijk denken en onderzoek hebben aan de basis gestaan van de juiste beeldvorming.

\section{Dankwoord}

Gekomen aan het einde van mijn les wil ik nog een dankwoord uitspreken.

Ten eerste wil ik het bestuur van de Stichting Wetenschapsbeoefening UM, het bestuur van CARIM en de decaan van de Faculteit van Health, Medicine en Life Sciences bedanken voor het in mij gestelde vertrouwen. Prof. Hemker, beste Coen als mijn promotor heb ik veel van je geleerd, met name hoe je de industrie kunt betrekken in je onderzoek. Op bijna onnavolgbare wijze wist je altijd discussies en onderhandelingen ongemerkt om te buigen naar een gevoel van vanzelfsprekendheid om met jou in zee te gaan. Je onuitputtelijke en onderhoudende verhalen hebben daar zeker aan bijgedragen. 
Prof. Hornstra, beste Gerard, als mijn directe begeleider van het eerste uur en co-promotor ben ik je dankbaar dat je mij hebt laten groeien in dit fantastische vak. Het allesbehalve rechte pad van mijn onderzoek dat ik heb geschetst lijkt te zijn ontstaan door toevalligheden. In zekere zin is dat ook zo maar de toevalligheden leiden alleen tot keuzes die er toe doen als er voldoende ruimte wordt geboden aan verwondering en nieuwsgierigheid. Deze ruimte heb je mij gegund. Jij hebt mij geleerd dat het soms beter is eerst te patenteren en dan te publiceren. In deze openbare les heb ik hopelijk duidelijk kunnen maken dat deze gedachte de onafhankelijkheid geenszins hoeft aan te tasten terwijl het de samenleving veel kan opleveren.

Prof. Narula, dear Jagatji, you have shown me the power of combining science with friendship. Your warm hospitality, your never ceasing energy and your brilliant and creative ideas have added a precious dimension to my perception of the meaning of science.

Prof. Hofstra, beste Leo, samen hebben we laten zien wat translationeel onderzoek nu feitelijk inhoudt. Onze samenwerking en vriendschap zijn niet geëindigd door je vertrek uit de universitaire wereld. Wel vind ik het jammer dat je de stap gemaakt hebt omdat ik er van overtuigd ben dat de universitaire wereld zulke kleurrijke mensen als jij nodig heeft.

Cecile, Petra, lisette, Heidi, Niko en Leon jullie vormen het fundament en het hart van het lab. Jullie zijn het dreamteam. Jullie hebben kennis, kunde, enthousiasme en teamspirit. Elke nieuwkomer in het lab wordt door jullie geinfecteerd en gaat dan niet in apoptose maar komt juist extra tot leven. Ik hoop nog lang met jullie te mogen samenwerken.

Nicole jouw vaardige handen maken het mogelijk om op verantwoorde wijze proefdierexperimenten uit te voeren. Kristof, Dennis en Martijn, als aanstormende talenten hebben jullie teamspirit getoond en zijn jullie enthousiast bezig het fundament van het lab te verfraaien met mooie bouwsels.

Lieve Cathelijne, Flip en Roosje, ik ben enorm trots op jullie en ontzettend blij dat ik dat vanaf hier kan zeggen. Lieve Patrice, elke dag met jou betekent weer een prachtige dag. Zonder jou zou ik hier zeker niet hebben gestaan. 
Ten slotte draag ik deze rede op aan de nagedachtenis van mijn ouders. Zij hebben in hun traditie het fundament gelegd waarop ik heb mogen verder bouwen. Ik hoop dat Patrice en ik de basis leggen waarop onze kinderen verder willen bouwen.

Ik heb gezegd.

\section{Literatuur}

1. Ronald W. Clark. 'Einstein: The Life and Times.' (Avon books) (1971) page 516.

2. Jonathan Swift. 'Writings on religion and the church.' Volume I (Temple Scott editor 1898, Gutenberg Project www.gutenberg.org/cache/epub/12252/pg12252.html).

3. Carl Vogt. 'Untersuchungen über die Entwicklungsgeschichte der Geburtshelferkröte.' (Jent und Gassman, Solothurn) (1842) page 130.

4. Walther Flemming. 'Uber die bildung von richtungsfiguren in saugethiereiern beim untergang graaf'scher Folikel', Arch. Anat. Entwgesch, (1885) 221-224.

5. Kerr, J.F., Wyllie, A.H. \& Currie A.R., 'Apoptosis: a basic biological phenomenon with wideranging implications in tissue kinetics', Br. J. Cancer (1972) 26: 239-257.

6. Editorial. 'Apoptosis.' Lancet (1972) 300:1011-1012.

7. Singer, S.J., and Nicolson, G.L. 'The fluid mosaic model of the structure of cell membranes, Science.' (1972) 175: 720-731.

8. Fadok, V. A., Voelker, D. R., Campbell, P. A., Cohen, J. J., Bratton, D. L., and Henson, P. M. 'Exposure of phosphatidylserine on the surface of apoptotic lymphocytes triggers specific recognition and removal by macrophages.' J. Immunol. (1992) 148: 2207-2216.

9. Reutelingsperger, C. P., Hornstra, G., and Hemker, H. C. 'Isolation and partial purification of a novel anticoagulant from arteries of human umbilical cord.' Eur. J. Biochem. (1985) 151: 625-629.

10. Hofstra, L., Liem, I. H., Dumont, E. A., Boersma, H. H., van Heerde, W. L., Doevendans, P. A., De Muinck, E., Wellens, H. J., Kemerink, G. J., Reutelingsperger, C. P., and Heidendal, G. A. 'Visualisation of cell death in vivo in patients with acute myocardial infarction.' Lancet (2000) 356: 209-212.

11. Haas, R. L., de Jong, D., Valdes Olmos, R. A., Hoefnagel, C. A., van den Heuvel, I., Zerp, S. F., Bartelink, H., and Verheij, M. 'In vivo imaging of radiation-induced apoptosis in follicular lymphoma patients.' Int. J. Radiat. Oncol. Biol. Phys. (2004) 59: 782-787. 
